\title{
Perbandingan Metode Koreksi Atmosfer Dark Spectrum Fitting dan Exponential Extrapolation untuk Citra Satelit Landsat 8 \\ Comparison of Dark Spectrum Fitting and Exponential Extrapolation Atmospheric Correction Methods for Landsat 8 Satellite Image
}

\section{Lalu Muhamad Jaelani*, Gilang Amrullah Sayono}

Departemen Teknik Geomatika, FTSPK-ITS, Kampus ITS Sukolilo, Surabaya, 60111, Indonesia

*Korespondensi penulis: 1mjaelani@geodesy.its.ac.id

Diterima: 04032021; Diperbaiki: 04082021; Disetujui: 08092021; Dipublikasi: 10012022

\begin{abstract}
Abstrak: Pemanfaatan citra satelit dalam penelitian penginderaan jauh semakin banyak dilakukan. Hal tersebut didukung oleh ketersediaan data yang berlimpah dengan cakupan spasial, spektral, dan temporal, serta kemudahan akses untuk mendapatkannya. Data citra satelit perlu melewati proses koreksi atmosfer agar dapat digunakan untuk identifikasi objek di permukaan bumi berdasarkan informasi spektralnya. Koreksi atmosfer dilakukan untuk menghilangkan pengaruh atmosfer pada data penginderaan jauh yang direkam oleh sensor. Permasalahan terkait pengaruh atmosfer tersebut lebih sering ditemukan pada perairan keruh. Kondisi perairan keruh ini banyak ditemukan pada danau, sungai, dan wilayah pesisir pantai. Oleh karena itu, penelitian dilakukan di Danau Matano dan Towuti, Danau Kasumigaura, dan perairan Pulau Poteran. Penelitian ini membandingkan dua metode koreksi atmosfer yaitu Exponential Extrapolation (EXP) dan Dark Spectrum Fitting (DSF). Data citra satelit yang digunakan adalah citra satelit Landsat 8. Hasil dari olahan kedua metode akan dibandingkan dengan data in situ berupa reflektan permukaan dan konsentrasi klorofil-a. Uji korelasi digunakan untuk mengetahui tingkat keeratan kedua metode tersebut. Hasil penelitian ini menunjukkan bahwa metode DSF memiliki hasil yang lebih baik dengan diperoleh hasil korelasi reflektan permukaan dengan nilai 0,905 untuk Danau Matano Towuti, 0,916 untuk Perairan Pulau Poteran, dan 0,973 untuk Danau Kasumigaura. Sedangkan untuk metode EXP dihasilkan nilai korelasi sebesar 0,905 untuk danau Matano Towuti, tidak terdefinisi untuk Perairan Pulau Poteran, dan 0,975 untuk Danau Kasumigaura. Hasil dari reflektan permukaan akan mempengaruhi nilai estimasi persebaran klorofil-a. Pengaruh ini dapat dilihat dari hasil perolehan hasil NMAE. Untuk metode DSF nilai NMAE berturut-turut sebesar 259,955\%, 93,258\%, dan 40,326\%. Sedangkan untuk metode EXP berturut-turut sebesar 259,955\%, tidak terdefinisi, dan 36,500\%.
\end{abstract}

Copyright (C) 2022 Geoid. All rights reserved.

\begin{abstract}
Abstract: Satellite imagery is increasingly being used in remote sensing research. This condition is due to abundant data with spatial, spectral, and temporal coverage and easy access to the data. Satellite image data needs to go through an atmospheric correction process for further use. Atmospheric correction is carried out to eliminate the atmosphere's influence on remote sensing data recorded by the sensor. Problems related to the influence of the atmosphere are more often found in turbid waters. These turbid waters are generally located on lakes, rivers, and coastal areas. Therefore, the research was carried out in Matano and Towuti Lakes, Kasumigaura Lake, and Poteran Island waters. This study compares two atmospheric correction methods: Exponential Extrapolation (EXP) and Dark Spectrum Fitting (DSF) using Landsat 8 satellite imagery. The results from the two methods were then compared with in situ data in surface reflectance and chlorophyll-a concentration. A correlation test was performed to determine the level of closeness of the two methods. This study indicates that the DSF performance was better than EXP by obtaining a surface reflectance correlation with a value of 0.905, 0.916, and 0.973 for Lake Matano Towuti, Poteran Island waters, and Kasumigaura Lake, respectively. For the EXP method, a correlation value was 0.905, undefined, 0.975 for Matano Towuti lake, Poteran Island waters, and Lake Kasumigaura. The result of surface reflectance will influence the estimated value of the chlorophyll-a distribution. This effect could be seen from the results of the Normalized Mean Absolute Error (NMAE) results. For the DSF method, the NMAE values were 259,955\%, 93,258\%, and 40,326\%, respectively. Meanwhile, the EXP method is 259,955\%, undefined, and 36,500\%, respectively.
\end{abstract}

Kata kunci : Dark Spectrum Fitting; Exponential Extrapolation; koreksi atmosfer; Landsat 8

Cara untuk sitasi: Sayono, G.A., Jaelani, L.M.. (2021). Perbandingan Metode Koreksi Atmosfer Dark Spectrum Fitting dan Exponential Extrapolation Untuk Citra Satelit Landsat 8. Geoid, 17(1), 38 - 52 


\section{Pendahuluan}

Perkembangan teknologi penginderaan jauh semakin membuka peluang untuk melakukan penelitian dengan memanfaatkan teknologi ini. Hal ini didukung juga dengan peluncuran citra satelit Landsat 8 (L8) pada tahun 2013 dan citra satelit Landsat 8 pada tahun 2015 yang memiliki cakupan spasial, spektral, dan temporal dan akses data gratis. Pembukaan arsip Landsat lengkap terutama untuk data Landsat 5 (L5) global, menambahkan dimensi temporal yang menarik untuk penginderaan jauh air pesisir dan pedalaman memungkinkan untuk studi jangka panjang (30+ tahun) (Woodcock, 2008). Dari segi akses data, Landsat telah mudah diakses secara gratis melalui portal terbuka seperti USGS Earth Explorer, Copernicus Science Hub, dan beberapa inisiatif pribadi seperti Google Earth Engine (GEE).

Data penginderaan jauh yang beragam tidak dapat digunakan secara langsung dalam penelitian. Data yang digunakan perlu dilakukan beberapa koreksi, salah satunya yaitu koreksi radiometrik. Koreksi radiometrik ini terdiri dari kalibrasi radiometrik dan koreksi atmosfer. Koreksi atmosfer diperlukan untuk menghilangkan pengaruh atmosfer pada data penginderaan jauh yang direkam oleh sensor. Hingga saat ini salah satu pengaruh atmosfer yang masih menjadi permasalahan adalah pengaruh atmosfer yang disebabkan oleh partikel (aerosol scattering) karena tidak dapat dihitung. Pada penelitian yang telah ada mengungkapkan bahwa kontribusi aerosol dapat diperkirakan setelah koreksi Rayleigh melalui penggunaan asumsi "piksel hitam" dalam NIR (Antoine \& Morel, 1999; Gordon \& Wang, 1994) atau kanal SWIR (Gao et al., 2007). Pantulan air NIR nol dapat dimodelkan menggunakan pendekatan iteratif berdasarkan konsentrasi klorofil turunan (Bailey et al., 2010) tetapi metode ini gagal di perairan yang sangat keruh (Dogliotti et al., 2016).

Pada penelitian ini dilakukan koreksi atmosfer pada citra landsat 8 dengan menggunakan metode koreksi atmosfer Dark Spectrum Fitting (Vanhellemont, 2019; Vanhellemont \& Ruddick, 2018) dan Exponential Extrapolation (Vanhellemont \& Ruddick, 2014, 2015, 2016). Pemilihan citra landsat 8 ini berhubungan dengan ketersediaan data temporal dari Landsat 8 . Hasil koreksi tersebut kemudian dihubungkan dengan data in situ. Untuk mengetahui pengaruh metode koreksi atmosfer tersebut terhadap parameter kualitas perairan digunakan parameter kualitas perairan berupa konsentrasi klorofil-a. Penelitian ini bertujuan untuk membandingkan antara metode koreksi atmosfer untuk citra satelit Landsat 8 dan mengetahui pengaruh koreksi atmosfer metode Exponential Extrapolation dan Dark Spectrum Fitting terhadap nilai estimasi klorofil-a yang dihasilkan oleh citra satelit Landsat 8. Sehingga, didapatkan rekomendasi metode koreksi yang sesuai untuk pengolahan citra satelit Landsat 8.

\section{Data dan Metode}

Penelitian ini diterapkan terhadap tiga set lokasi. Lokasi pertama yaitu Danau Towuti yang terletak pada koordinat $2^{\circ} 45^{\prime} 0^{\prime \prime} \mathrm{LU}, 121^{\circ} 30^{\prime} 0^{\prime \prime} \mathrm{BT}$ dan Danau Matano yang terletak pada koordinat $2^{\circ} 52^{\prime} \mathrm{LU}, 121^{\circ} 36^{\prime} \mathrm{BT}$. Lokasi kedua yaitu Perairan Pulau Poteran, Sumenep, Jawa Timur yang terletak pada koordinat $113,94^{\circ}$ BT dan $7,07^{\circ} \mathrm{LS}$ sampai $114,06^{\circ} \mathrm{BT}$ dan $7,10^{\circ} \mathrm{LS}$. Lokasi ketiga yaitu Danau Kasumigaura, Jepang yang terletak pada koordinat $35^{\circ} 57^{\prime} 3,30^{\prime \prime} \mathrm{LU}$ sampai dengan $36^{\circ} 9^{\prime} 40,67^{\prime \prime} \mathrm{LU}$ dan $140^{\circ} 11^{\prime} 52,06$ "BT. Pemilihan lokasi ini berdasarkan pertimbangan kondisi perairan yang terdapat banyak partikel kecil seperti pasir atau partikel lain yang tersuspensi di dalamnya membatasi transmisi cahaya, sehingga mengindikasikan sebagai perairan keruh. Pada Gambar 1. di bawah ini menunjukkan lokasi penelitian yang digunakan.

Data yang digunakan pada penelitian ini yaitu data citra satelit Landsat 8 level 1 dan data in situ. Adapun rincian dari setiap data yang digunakan ditunjukkan pada Tabel 1. dan Tabel 2. dibawah ini. Pada penelitian ini, pengolahan dilakukan dengan aplikasi pengolahan citra satelit, ACOLITE (Atmospheric Correction for OLI 'lite') yang dapat diakses melalui https://odnature.naturalsciences.be/remsem/software-and-data/acolite 


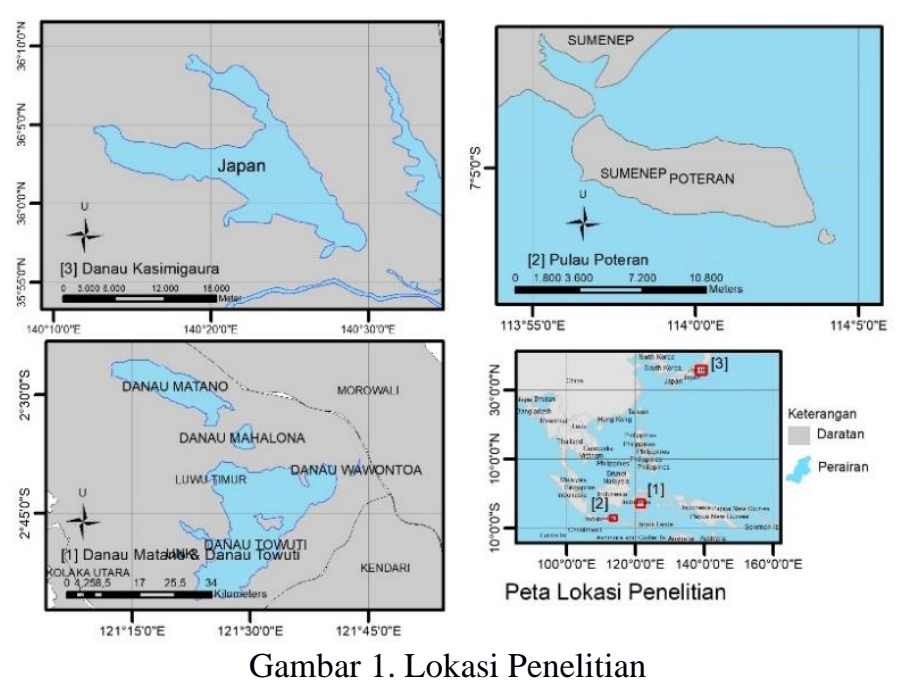

Tabel 1. Data Citra Satelit Landsat 8 Level 1

\begin{tabular}{cccc}
\hline \hline No. & Lokasi & Keterangan & Tanggal Akuisisi \\
\hline 1. & $\begin{array}{c}\text { Danau Matano dan } \\
\text { Towuti }\end{array}$ & Path $=113$, Row $=62$ & 16 Oktober 2014 \\
\hline 2. & $\begin{array}{c}\text { Danau Kasumigaura, } \\
\text { Jepang }\end{array}$ & Path $=107$, Row $=35$ & 18 Februari 2006 \\
\hline 3. & Perairan Pulau Poteran & Path $=117$, Row $=65$ & 22 April 2015 \\
\hline \hline
\end{tabular}

Tabel 2. Tabel In Situ

\begin{tabular}{ccc}
\hline \hline No. & Data & Keterangan \\
\hline 1. & $\begin{array}{c}\text { Remote Sensing } \\
\text { Reflectance }(\operatorname{Rrs}(\lambda))\end{array}$ & $\begin{array}{c}\text { Berupa Remote Sensing Reflectance }(\operatorname{Rrs}(\lambda)) \\
\text { dari titik sampel yang telah diambil. } \\
\text { Diperoleh secara langsung di lapangan. }\end{array}$ \\
\hline Klorofil-a & $\begin{array}{c}\text { Berupa konsentrasi klorofil-a dari titik sampel } \\
\text { yang telah diambil. Diperoleh secara } \\
\text { langsung di lapangan }\end{array}$ \\
\hline 3. & Data Koordinat Titik & $\begin{array}{c}\text { Berupa koordinat dari titik sampel yang telah } \\
\text { diambil secara langsung di lapangan. }\end{array}$ \\
\hline \hline
\end{tabular}

Proses pengolahan data dimulai dari proses koreksi atmosfer untuk data Landsat 8 dan perhitungan $\operatorname{Rrs}(\lambda)$ untuk data in situ. Data Landsat 8 yang digunakan harus dijadikan $\operatorname{Rrs}(\lambda)$ agar bisa dilihat nilai keakuratan jika dibandingkan dengan data in situ. Pengolahan data yang dilakukan dibagi menjadi dua bagian, yaitu proses pengolahan data in situ $\operatorname{Rrs}(\lambda)$ dan proses pengolahan citra satelit Landsat 8. Pada pengolahan data in situ dilakukan klasifikasi $\operatorname{Rrs}(\lambda)$ sesuai dengan kanal yang ada di Landsat 8 . Hal ini dilakukan dengan cara melihat panjang gelombang data in situ $\operatorname{Rrs}(\lambda)$, disesuaikan dengan panjang gelombang pada kanal Landsat 8 .

Tahap pengolahan Citra Satelit Landsat 8 dilakukan koreksi atmosfer metode Exponential Extrapolation dan Dark Spectrum Fitting pada citra satelit Landsat 8 Level 1C yang masih berupa reflektan sensor (Top-OfAtmosphere (TOA)), yang kemudian menghasilkan Landsat 8 Level-2 yang dalam bentuk reflektan permukaan (surface reflectance, Bottom-Of-Atmosphere (BOA)). Selanjutnya, pada tahapan pengubahan Surface Reflectance (sr) menjadi $\operatorname{Rrs}(\lambda)$, sr dibagi dengan $\pi$ untuk menghasilkan $\operatorname{Rrs}(\lambda)$ (dalam satuan sr-1) agar memiliki satuan yang sama dengan reflektan in situ sehingga dapat dilakukan perbandingan. Tahap berikutnya masuk pada proses ekstraksi $\operatorname{Rrs}(\lambda)$ pada setiap stasiun. Proses ini dilakukan dengan cara mencari rata-rata nilai pixel berdasarkan letak titik stasiun yang digunakan sebagai tempat pengambilan data in situ. Hal ini penting dilakukan karena jendela piksel memberi perkiraan variabilitas spasial dan untuk menghindari kemungkinan adanya kesalahan dalam koreksi geometrik dan dinamika badan air, penggunaan jendela piksel untuk menghindari kesalahan karena perbedaan koordinat yang mungkin terjadi jika hanya menggunakan satu 
piksel. Proses selanjutnya adalah perhitungan klorofil-a pada setiap stasiun. Perhitungan Klorofil-a ini bertujuan untuk menghasilkan nilai Klorofil-a sesuai koordinat stasiun pengambilan data in situ Klorofil-a.. Berikut adalah algoritma estimasi klorofil-a yang digunakan pada tiap lokasi. Persamaan (1) merupakan algoritma (Jaelani et al., 2015) untuk perhitungan klorofil-a Danau Matano dan Towuti, persamaan (2) merupakan algoritma (Laili et al., 2015) untuk lokasi Pulau Poteran, dan persamaan (3) merupakan algoritma (Salem et al., 2017) untuk Danau Kasumigaura.

$$
\begin{aligned}
& \text { Chla }=-0.9889\left(\frac{\operatorname{Rrs} 4}{\operatorname{Rrs5}}\right)+0.3619 \\
& \text { Chl }-a=4180,5\left(\frac{\log R r s 2}{\log R r s 4}\right)-6211,4\left(\frac{\log R r s 2}{\operatorname{LogRrs} 4}\right)+2540,2 \\
& \text { Chla } \propto\left(\frac{\operatorname{Rrs}\left(\lambda_{2}\right)-\operatorname{Rrs}\left(\lambda_{1}\right)}{\operatorname{Rrs}\left(\lambda_{2}\right)+\operatorname{Rrs}\left(\lambda_{1}\right)}\right)
\end{aligned}
$$

Selanjutnya, pada akhir pengolahan dilakukan validasi dari $\operatorname{Rrs}(\lambda)$-Exponential Extrapolation dan Dark Spectrum Fitting dengan $\operatorname{Rrs}(\lambda)$ data in situ. Selain itu juga dilakukan validasi terhadap hasil estimasi Klorofila terhadap Klorofil-a data in situ, untuk mengetahui hubungan dari nilai akurasi $\operatorname{Rrs}(\lambda)$ Exponential Extrapolation dan Dark Spectrum Fitting terhadap estimasi Klorofil-a yang dihasilkan. Validasi ini menggunakan 2 jenis uji statistik, yaitu Uji Koefisien Determinasi $\left(\mathrm{R}^{2}\right)$ dan uji akurasi menggunakan RMSE dan Normalized Mean Absolute Error (NMAE).

\section{Hasil dan Pembahasan}

\section{Hasil Pengolahan Produk Rrs( $(\lambda)$ Exponential Extrapolation dan Rrs $(\lambda)$ Dark Spectrum Fitting}

Hasil pengolahan produk $\operatorname{Rrs}(\lambda)$ Exponential Extrapolation dan $\operatorname{Rrs}(\lambda)$ Dark Spectrum Fitting dijelaskan berdasarkan masing-masing lokasi penelitian. Pengujian akurasi nilai $\operatorname{Rrs}(\lambda)$ yang sudah terkoreksi dari efek atmosfer baik menggunakan metode Exponential Extrapolation atau Dark Spectrum Fitting dilakukan dengan mencari rata-rata nilai piksel yang diekstrak pada titik titik stasiun pengamatan yang nantinya akan dibandingkan dengan $\operatorname{Rrs}(\lambda)$ in-situ. Uji korelasi ini dilakukan dengan menggunakan regresi linear sederhana yang bertujuan untuk mengetahui hubungan antara hasil pengolahan data citra yang sudah dilakukan koreksi atmosfer dan data yang diperoleh di lapangan secara langsung serta menggunakan fungsi koefisien determinasi (R2). Setelah diketahui nilai korelasi masing-masing nilai $\operatorname{Rrs}(\lambda)$ selanjutnya dilakukan uji validasi untuk mengetahui apakah metode yang digunakan sesuai atau belum. Uji validasi pada penelitian ini menggunakan metode Normalized mean Absolute Error (NMAE) dengan toleransi absolut error sebesar $\leq 30 \%$ (Jaelani, 2016) serta menggunakan Root Mean Square Error (RMSE).

\section{2. $\operatorname{Rrs}(\lambda)$ pada Danau Matano dan Towuti}

Hasil perhitungan $\operatorname{Rrs}(\lambda)$ pada daerah Danau Matano dan Towuti ditunjukkan oleh Tabel 3. dan tabel 4. di bawah ini.

Tabel 3. Hasil perhitungan data $\operatorname{Rrs}(\lambda)$ in-situ dengan $\operatorname{Rrs}(\lambda)$ hasil koreksi atmosfer menggunakan metode Exponential Extrapolation

\begin{tabular}{ccccc}
\hline \hline Stasiun & $\mathbf{R}^{\mathbf{2}}$ & $\mathbf{r}$ & $\begin{array}{c}\text { NMAE } \\
(\boldsymbol{\%})\end{array}$ & RMSE \\
\hline Ma, 1 & 0,636 & 0,797 & 146,033 & 0,089 \\
\hline Ma,2 & 0,606 & 0,778 & 57,452 & 0,055 \\
\hline $\mathrm{a}, 3$ & 0,907 & 0,952 & 30,699 & 0,038 \\
\hline To, 1 & 0,936 & 0,967 & 143,209 & 0,065 \\
\hline To,2 & 0,946 & 0,973 & 71,907 & 0,045 \\
\hline To,3 & 0,926 & 0,963 & 73,427 & 0,047 \\
\hline Rata - rata & 0,826 & 0,905 & 87,121 & 0,056 \\
\hline \hline
\end{tabular}


Tabel 4. Hasil perhitungan data $\operatorname{Rrs}(\lambda)$ in-situ dengan $\operatorname{Rrs}(\lambda)$ hasil koreksi atmosfer menggunakan metode Dark Spectrum Fitting

\begin{tabular}{ccccc}
\hline \hline Stasiun & $\mathbf{R}^{\mathbf{2}}$ & $\mathbf{r}$ & $\begin{array}{c}\text { NMAE } \\
\mathbf{( \% )}\end{array}$ & RMSE \\
\hline Ma, 1 & 0,636 & 0,797 & 146,033 & 0,089 \\
\hline Ma,2 & 0,606 & 0,778 & 57,452 & 0,055 \\
\hline $\mathrm{a}, 3$ & 0,907 & 0,952 & 30,699 & 0,038 \\
\hline To, 1 & 0,936 & 0,967 & 143,209 & 0,065 \\
\hline To,2 & 0,946 & 0,973 & 71,907 & 0,045 \\
\hline To,3 & 0,926 & 0,963 & 73,427 & 0,047 \\
\hline Rata -rata & 0,826 & 0,905 & 87,121 & 0,056 \\
\hline \hline
\end{tabular}

Hasil rata-rata koefisien determinasi $\left(\mathrm{R}^{2}\right)$ antara $\operatorname{Rrs}(\lambda)$ in-situ dengan $\operatorname{Rrs}(\lambda)$ hasil olahan sebesar 0,826 yang menandakan dua variabel memiliki hubungan yang kuat. Untuk kasus kali ini didapatkan nilai koefisien determinasi $\left(\mathrm{R}^{2}\right)$ yang sama antara kedua metode yang digunakan. Begitu pula dengan nilai koefisien korelasi (r) antara $\operatorname{Rrs}(\lambda)$ in-situ dan $\operatorname{Rrs}(\lambda)$ hasil olahan dengan rata-rata sebesar 0,905 . Untuk nilai rata-rata $R M S E$ dan NMAE yang dihasilkan oleh $\operatorname{Rrs}(\lambda)$ in-situ dan $\operatorname{Rrs}(\lambda)$ hasil olahan sebesar 0,056 dan 87,121\%. Untuk nilai $R M S E$ dan $N M A E$ dari kedua metode juga didapatkan nilai yang sama. Jika melihat nilai $N M A E$ yang dihasilkan $\operatorname{Rrs}(\lambda)$ in-situ dan $\operatorname{Rrs}(\lambda)$ hasil olahan dari kedua metode memiliki nilai NMAE yang belum memenuhi persyaratan untuk mengekstrak data kualitas air dari data penginderaan jauh karena nilai NMAE belum di atas syarat minum yaitu $\leq 30 \%$.

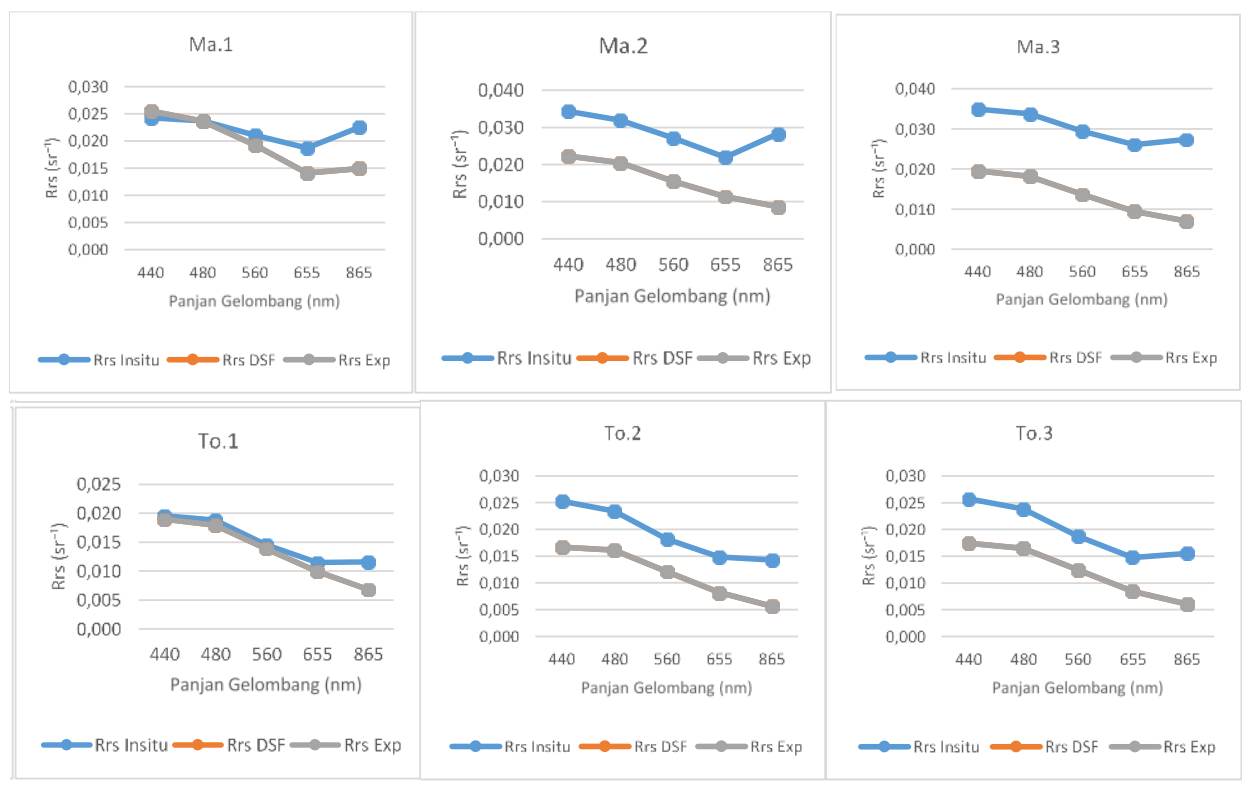

Gambar 2. Grafik perbandingan $\operatorname{Rrs}(\lambda)$ in-situ dan $\operatorname{Rrs}(\lambda)$ hasil olahan metode Exponential Extrapolation dan Dark Spectrum Fitting pada Danau Matano dan Towuti

Pada Gambar 2. diatas menampilkan grafik hasil perbanding antara $\operatorname{Rrs}(\lambda)$ in-situ dan $\operatorname{Rrs}(\lambda)$ hasil olahan pada 6 titik stasiun Pengamatan. Dari 6 grafik tersebut dapat dilihat bahwa nilai $\operatorname{Rrs}(\lambda)$ in-situ dominan lebih tinggi nilainya dari $\operatorname{Rrs}(\lambda)$ hasil olahan. Dalam kasus ini nilai Rrs $(\lambda)$ hasil olahan kedua metode menghasilkan nilai yang sama.

Pada Gambar 3 menunjukkan hubungan nilai $\operatorname{Rrs}(\lambda)$ antara hasil olahan metode Exponential Extrapolation dan Dark Spectrum Fitting. Hasil yang sama antara kedua metode menyebabkan grafik antara kedua metode tersebut saling bertumpukkan. 


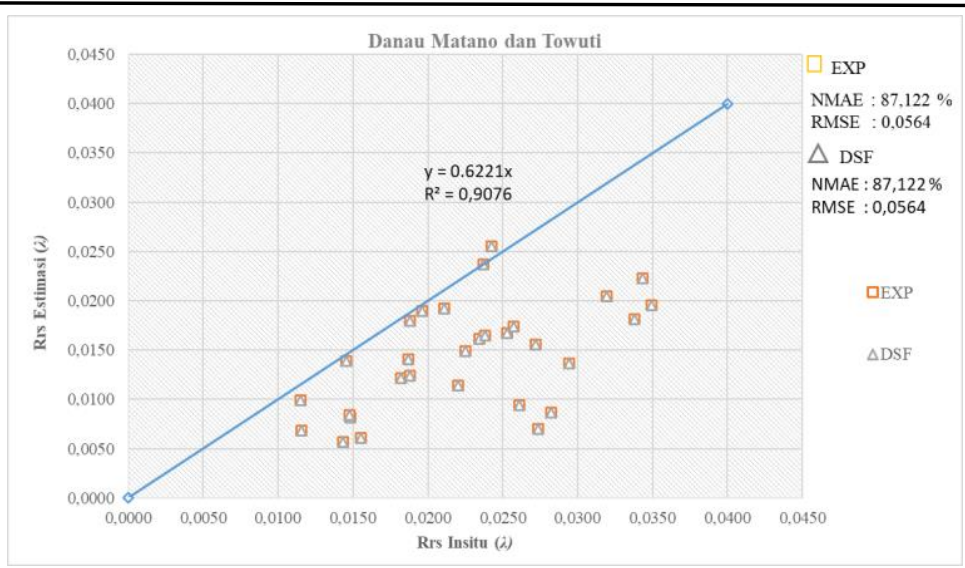

Gambar 3. Grafik Hubungan Nilai Rrs $(\lambda)$

\section{3. $\operatorname{Rrs}(\lambda)$ Perairan Pulau Poteran, Sumenep}

Proses perhitungan $\operatorname{Rrs}(\lambda)$ yang metode Exponential Extrapolation menghasilkan nilai yang terdefinisi. Hanya pada titik pengamatan dengan kode St.3 yang dapat menghasilkan nilai yang kemudian bisa dibandingkan dengan data $\operatorname{Rrs}(\lambda)$ in-situ. Permasalahan yang menyebabkan metode Exponential Extrapolation tidak dapat memperoleh nilai $\operatorname{Rrs}(\lambda)$ dikarenakan kondisi citra satelit dalam keadaan tutupan awan sebesar $54 \%$ dan lokasi Perairan Pulau Poteran sebagian tertutup awan. Hasil dari itu mempengaruhi nilai kanal SWIR yang digunakan untuk melakukan ekstrapolasi semua kanal lainnya. Berikut ini adalah tabel hasil perhitungan pada daerah Perairan Pulau Poteran, Sumenep. Tabel 5 dan Tabel 6 berikut menunjukkan hasil perhitungan di perairan Pulau Poteran.

Tabel 5. Hasil perhitungan data $\operatorname{Rrs}(\lambda)$ in-situ dengan $\operatorname{Rrs}(\lambda)$ hasil koreksi atmosfer menggunakan metode Exponential Extrapolation

\begin{tabular}{ccccc}
\hline \hline Stasiun & $\mathbf{R}^{\mathbf{2}}$ & $\mathbf{r}$ & $\begin{array}{c}\text { NMAE } \\
(\boldsymbol{\%})\end{array}$ & RMSE \\
\hline St.1 & $\mathrm{NaN}$ & $\mathrm{NaN}$ & $\mathrm{NaN}$ & $\mathrm{NaN}$ \\
\hline St.3 & 0,993 & 0,996 & 40,302 & 0,018 \\
\hline St.4 & $\mathrm{NaN}$ & $\mathrm{NaN}$ & $\mathrm{NaN}$ & $\mathrm{NaN}$ \\
\hline St.5 & $\mathrm{NaN}$ & $\mathrm{NaN}$ & $\mathrm{NaN}$ & $\mathrm{NaN}$ \\
\hline St.6 & $\mathrm{NaN}$ & $\mathrm{NaN}$ & $\mathrm{NaN}$ & $\mathrm{NaN}$ \\
\hline St.7 & $\mathrm{NaN}$ & $\mathrm{NaN}$ & $\mathrm{NaN}$ & $\mathrm{NaN}$ \\
\hline St.9 & $\mathrm{NaN}$ & $\mathrm{NaN}$ & $\mathrm{NaN}$ & $\mathrm{NaN}$ \\
\hline \hline
\end{tabular}

Tabel 6. . Hasil perhitungan data $\operatorname{Rrs}(\lambda)$ in-situ dengan $\operatorname{Rrs}(\lambda)$ hasil koreksi atmosfer menggunakan metode Dark Spectrum Fitting

\begin{tabular}{ccccc}
\hline \hline Stasiun & $\mathbf{R}^{\mathbf{2}}$ & $\mathbf{r}$ & $\begin{array}{c}\text { NMAE } \\
(\boldsymbol{\%})\end{array}$ & RMSE \\
\hline St.1 & 0,690 & 0,831 & 603,518 & 0,044 \\
\hline St.3 & 0,991 & 0,996 & 38,402 & 0,017 \\
\hline St.4 & 0,979 & 0,990 & 27,752 & 0,014 \\
\hline St.5 & 0,861 & 0,928 & 33,978 & 0,016 \\
\hline St.6 & 0,871 & 0,933 & 42,168 & 0,030 \\
\hline St.7 & 0,661 & 0,813 & 32,056 & 0,009 \\
\hline St.9 & 0,852 & 0,923 & 377,243 & 0,015 \\
\hline \hline
\end{tabular}

Hasil rata-rata koefisien determinasi $\left(\mathrm{R}^{2}\right)$ antara $\operatorname{Rrs}(\lambda)$ in-situ dengan $\operatorname{Rrs}(\lambda)$ hasil olahan menggunakan metode Exponential Extrapolation tidak dapat terdefinisi yang menandakan data in situ tidak berpengaruh terhadap data estimasi. Pada hasil rata-rata koefisien determinasi (R2) antara $\operatorname{Rrs}(\lambda)$ in-situ dengan $\operatorname{Rrs}(\lambda)$ hasil olahan menggunakan metode Dark Spectrum Fitting sebesar 0,844 yang menandakan hubungan antara 
kedua variabel kuat. Untuk kasus kali ini didapatkan nilai koefisien determinasi (R2) dan $\mathrm{r}$ yang tidak terdefinisi antara $\operatorname{Rrs}(\lambda)$ in-situ dan $\operatorname{Rrs}(\lambda)$ hasil olahan metode Exponential Extrapolation. Untuk nilai koefisien korelasi pada metode Dark Spectrum Fitting sebesar 0,916. Untuk nilai rata-rata RMSE dan NMAE yang dihasilkan oleh $\operatorname{Rrs}(\lambda)$ in-situ dan $\operatorname{Rrs}(\lambda)$ hasil olahan metode Dark Spectrum Fitting sebesar 0,017 dan 165,017\%. Untuk nilai RMSE dan NMAE dari metode Exponential Extrapolation tidak terdefinisi. Jika melihat nilai NMAE yang dihasilkan $\operatorname{Rrs}(\lambda)$ in-situ dan $\operatorname{Rrs}(\lambda)$ hasil olahan metode Dark Spectrum Fitting memiliki nilai NMAE yang belum memenuhi persyaratan untuk mengekstrak data kualitas air dari data penginderaan jauh karena nilai NMAE belum di atas syarat minimum yaitu $\leq 30 \%$.

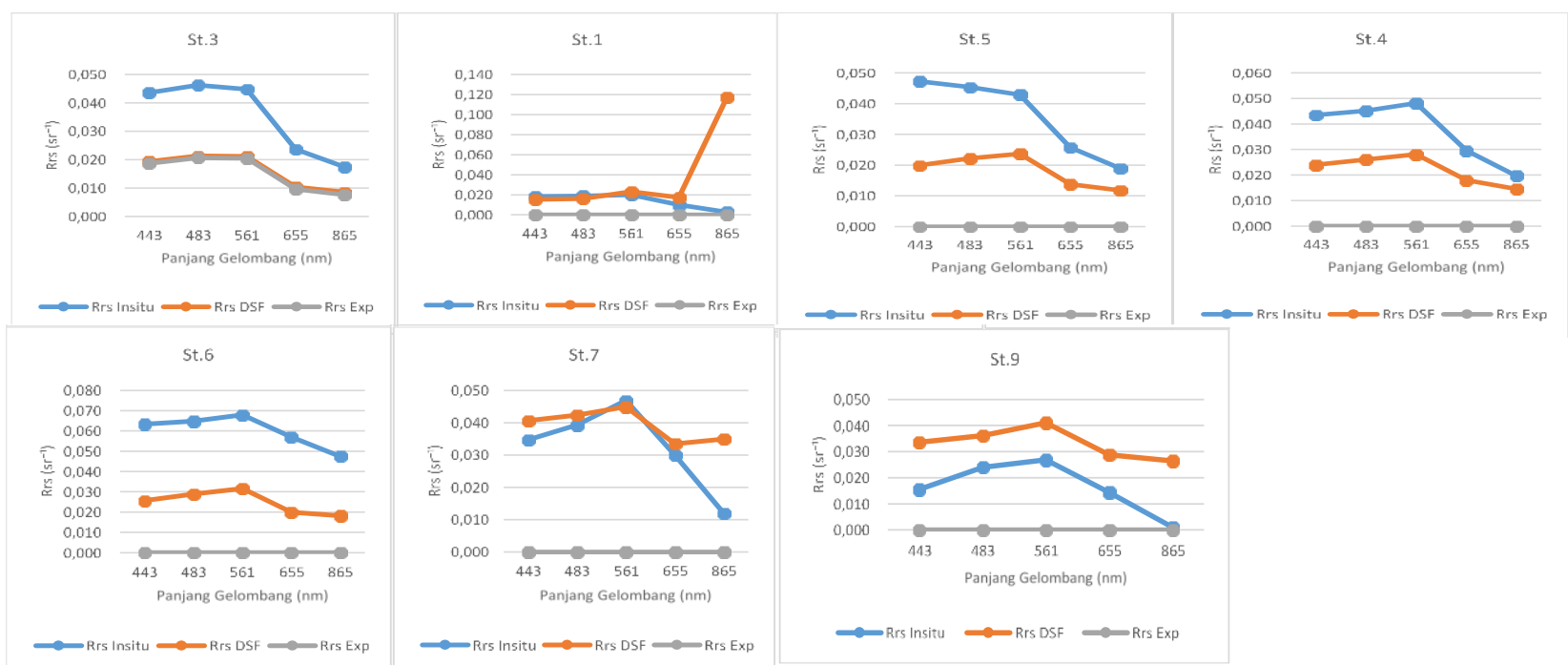

Gambar 4. Grafik perbandingan $\operatorname{Rrs}(\lambda)$ in-situ dan $\operatorname{Rrs}(\lambda)$ hasil olahan metode Exponential Extrapolation dan Dark Spectrum Fitting pada Perairan Pulau Poteran

Gambar 4 dibawah ini menampilkan grafik hasil perbandingan antara $\operatorname{Rrs}(\lambda)$ in-situ dari metode Exponential Extrapolation dan Dark Spectrum Fitting dan $\operatorname{Rrs}(\lambda)$ hasil olahan pada 7 titik stasiun Pengamatan. Dari 7 grafik tersebut dapat dilihat bahwa nilai $\operatorname{Rrs}(\lambda)$ Dark Spectrum Fitting dominan lebih tinggi nilainya dari $\operatorname{Rrs}(\lambda)$ in-situ, sedangkan untuk metode Exponential Extrapolation tidak terdefinisi.

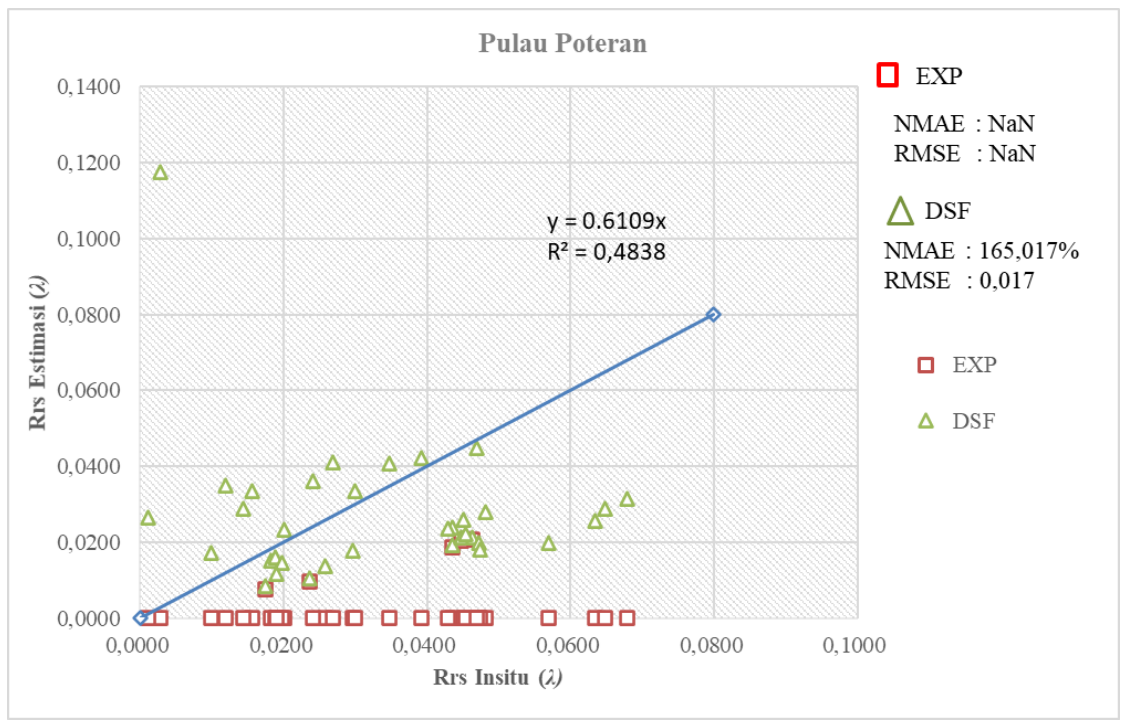

Gambar 5. Grafik Hubungan nilai Rrs $(\lambda)$

Gambar 5 menunjukkan hubungan nilai $\operatorname{Rrs}(\lambda)$ antara hasil olahan metode Exponential Extrapolation dan Dark Spectrum Fitting. Namun untuk metode Exponential Extrapolation tidak dapat menghasilkan nilai sehingga hubungan antara dua hasil olahan memiliki hubungan yang dikategorikan cukup tinggi. 


\section{4. $\operatorname{Rrs}(\lambda)$ Pada Danau Kasumigaura, Jepang}

Hasil dari perhitungan pada lokasi Danau Kasumigaura, Jepang ditunjukkan oleh Tabel 7 dan Tabel 8 di bawah ini.

Tabel 7. Hasil perhitungan data $\operatorname{Rrs}(\lambda)$ in-situ dengan $\operatorname{Rrs}(\lambda)$ hasil koreksi atmosfer menggunakan metode Exponential Extrapolation

\begin{tabular}{ccccc}
\hline \hline Stasiun & $\mathbf{R}^{2}$ & $\mathbf{r}$ & $\begin{array}{c}\text { NMAE } \\
(\mathbf{\%})\end{array}$ & $\mathbf{R M S E}$ \\
\hline St.1 & 0,9668 & 0,9833 & 12,5979 & 0,0020 \\
\hline St.2 & 0,8744 & 0,9351 & 22,1657 & 0,0029 \\
\hline St.3 & 0,9475 & 0,9734 & 61,2052 & 0,0044 \\
\hline St.5 & 0,9550 & 0,9773 & 62,3430 & 0,0050 \\
\hline st.6 & 0,9969 & 0,9985 & 11,9579 & 0,0025 \\
\hline st.7 & 0,9328 & 0,9658 & 127,7243 & 0,0078 \\
\hline st.8 & 0,9851 & 0,9925 & 90,8770 & 0,0047 \\
\hline Rata-rata & 0,9512 & 0,9751 & 55,5530 & 0,0042 \\
\hline \hline
\end{tabular}

Tabel 8. Hasil perhitungan data $\operatorname{Rrs}(\lambda)$ in-situ dengan $\operatorname{Rrs}(\lambda)$ hasil koreksi atmosfer menggunakan metode Dark Spectrum Fitting

\begin{tabular}{ccccc}
\hline \hline Stasiun & $\mathbf{R}^{2}$ & $\mathbf{r}$ & $\begin{array}{c}\text { NMAE } \\
(\boldsymbol{\%})\end{array}$ & $\mathbf{R M S E}$ \\
\hline St.1 & 0,9627 & 0,9812 & 17,1093 & 0,0022 \\
\hline St.2 & 0,8660 & 0,9306 & 26,6250 & 0,0034 \\
\hline St.3 & 0,9423 & 0,9707 & 68,1452 & 0,0049 \\
\hline St.5 & 0,9502 & 0,9748 & 68,5566 & 0,0055 \\
\hline st.6 & 0,9958 & 0,9979 & 16,5295 & 0,0026 \\
\hline st.7 & 0,9281 & 0,9634 & 136,6374 & 0,0083 \\
\hline st.8 & 0,9847 & 0,9923 & 100,7130 & 0,0052 \\
\hline Rata-rata & 0,9471 & 0,9730 & 62,0451 & 0,0046 \\
\hline \hline
\end{tabular}

Pada hasil perhitungan data $\operatorname{Rrs}(\lambda)$ in-situ dengan $\operatorname{Rrs}(\lambda)$ hasil koreksi atmosfer menggunakan metode Exponential Extrapolation didapatkan nilai koefisien determinasi sebesar 0,9512 yang menunjukkan hubungan antara kedua variabel kuat. Melihat hasil perhitungan data $\operatorname{Rrs}(\lambda)$ in-situ dengan $\operatorname{Rrs}(\lambda)$ hasil koreksi atmosfer menggunakan metode Dark Spectrum Fitting didapatkan koefisien determinasi sebesar 0,9471. Nilai koefisien korelasi (r) berbanding lurus dengan nilai (R2) yaitu sebesar 0,9730 yang juga menandakan adanya keeratan hubungan antara kedua produk ini. Sedangkan untuk nilai RMSE dari kedua metode ini sebesar 0,0042 dan 0,0046. Jika melihat nilai NMAE dari kedua metode ini bisa dikatakan nilai NMAE ini belum memenuhi syarat untuk mengekstrak data kualitas air dari data penginderaan jauh yang syaratnya harus $\leq 30 \%$. Sedangkan untuk nilai NMAE kedua metode tersebut sebesar 55,553\% dan 62,045\%.

Gambar 6 menampilkan grafik hasil perbandingan antara $\operatorname{Rrs}(\lambda)$ in-situ dan $\operatorname{Rrs}(\lambda)$ hasil olahan pada 7 titik stasiun pengamatan. Dari 7 grafik tersebut dapat dilihat bahwa nilai $\operatorname{Rrs}(\lambda)$ Exponential Extrapolation dominan lebih tinggi nilainya dari Rrs $(\lambda)$ metode Dark Spectrum fitting dan Rrs $(\lambda)$ in-situ. Sedangkan pada Gambar 7 menunjukkan hubungan nilai $\operatorname{Rrs}(\lambda)$ antara hasil olahan metode Exponential Extrapolation dan Dark Spectrum Fitting. Dari grafik tersebut dapat ditarik pengertian bahwa hubungan antara nilai $\operatorname{Rrs}(\lambda)$ kedua metode termasuk tinggi jika melihat nilai $\mathrm{R}^{2}$. 


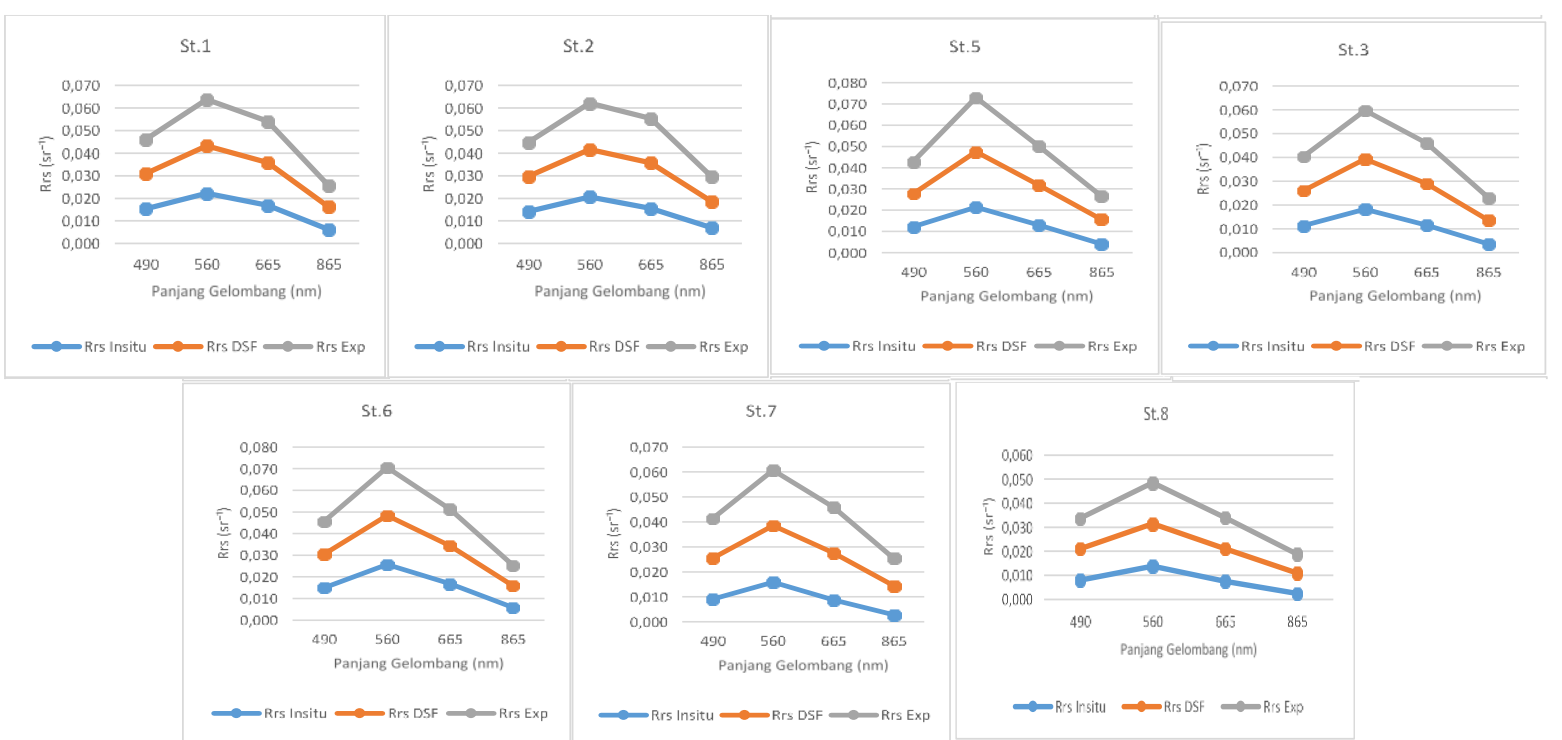

Gambar 6. Grafik perbandingan $\operatorname{Rrs}(\lambda)$ in-situ dan $\operatorname{Rrs}(\lambda)$ hasil olahan metode Exponential Extrapolation dan Dark Spectrum Fitting pada Danau Kasumigaura, Jepang

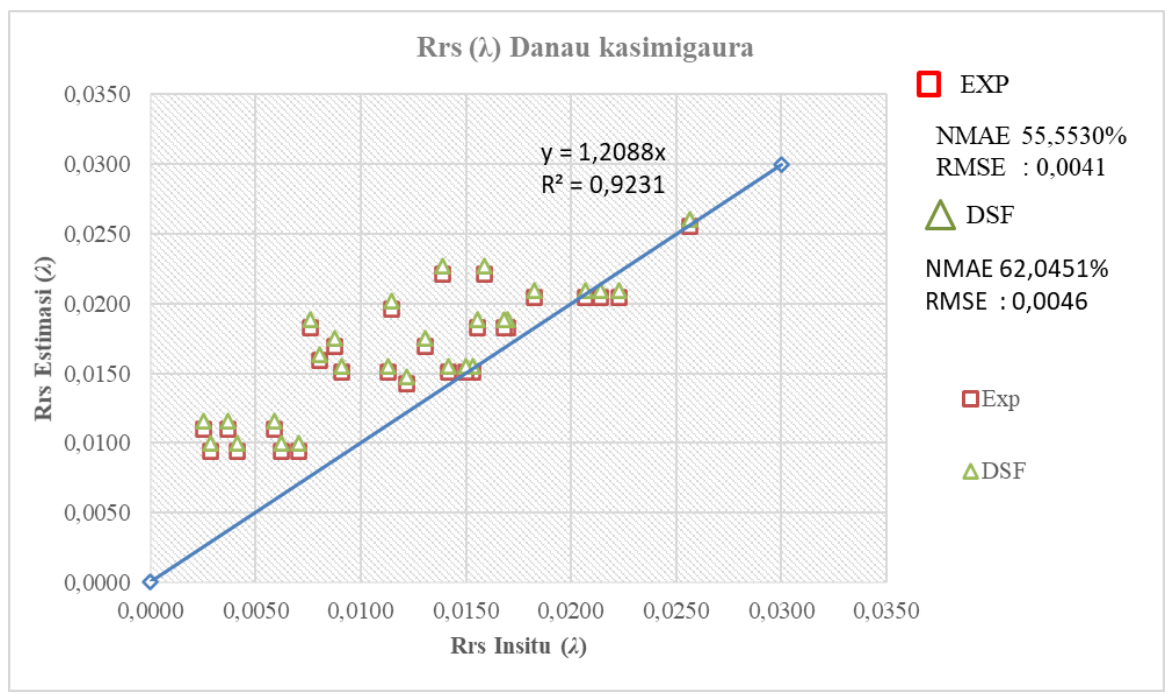

Gambar 7. Grafik Hubungan Nilai Rrs $(\lambda)$

\section{Hasil Pengolahan Nilai Estimasi Klorofil-a Danau Matano dan Towuti}

Tabel 9. Nilai Estimasi Klorofil-a Danau Matano dan Towuti

\begin{tabular}{cccc}
\hline \hline \multirow{2}{*}{ Stasiun } & \multicolumn{3}{c}{ Klorofil-a $(\mu \mathrm{g} / \mathrm{L})$} \\
\cline { 2 - 4 } & In situ & Exp & DSF \\
\hline Ma, 1 & 0,428 & 0,573 & 0,573 \\
\hline Ma,2 & 0,335 & 0,932 & 0,932 \\
\hline Ma,3 & 0,190 & 0,973 & 0,973 \\
\hline To,1 & 0,297 & 1,073 & 1,073 \\
\hline To,2 & 0,196 & 1,070 & 1,070 \\
\hline Тo,3 & 0,308 & 1,012 & 1,012 \\
\hline \hline
\end{tabular}

Syarat minimum untuk dapat melakukan ekstraksi data kualitas air dari data penginderaan jauh belum terpenuhi dengan nilai NMAE $\leq 30 \%$. Dari perhitungan nilai NMAE tersebut seharusnya belum bisa dilakukan proses selanjutnya. Namun, untuk melihat pengaruh terhadap klorofil-a dilakukan proses selanjutnya yaitu 
mengekstrak data kualitas air yaitu klorofil-a. Perhitungan nilai estimasi klorofil-a dilakukan berdasarkan algoritma yang telah ditentukan pada masing-masing lokasi.

Tabel 9 menunjukkan perbandingan nilai estimasi klorofil-a yang telah diekstrak dari data penginderaan jauh yang sudah melalui proses koreksi atmosfer dengan dua metode yang berbeda. Dalam kasus ini didapatkan nilai estimasi klorofil-a yang sama walaupun pada prosesnya menggunakan dua metode yang berbeda. Hasil dari nilai estimasi dari kedua metode masuk dalam klasifikasi oligotrof karena nilai estimasi lebih kecil dari 2 $\mu \mathrm{g} / \mathrm{L}$.

Tabel 10. Hasil Perhitungan $\mathrm{R}^{2}$, NMAE, RMSE klorofil-a Danau Matano dan Towuti

\begin{tabular}{ccccc}
\hline $\begin{array}{c}\text { Metode } \\
\text { Koreksi }\end{array}$ & $\mathrm{R}^{2}$ & $\mathrm{r}$ & $\mathrm{NMAE}(\%)$ & $\mathrm{RMSE}(\mu \mathrm{g} / \mathrm{L})$ \\
\hline Exp & 0,583 & $-0,764$ & 259,995 & 0,689 \\
\hline DSF & 0,583 & $-0,764$ & 259,995 & 0,689 \\
\hline \hline
\end{tabular}

Melihat nilai koefisien korelasi bernilai negatif menunjukkan hubungan antara nilai estimasi klorofil-a yang melalui proses koreksi atmosfer dengan dua metode dan nilai in-situ klorofil-a memiliki hubungan yang bertolak belakang atau tidak searah.

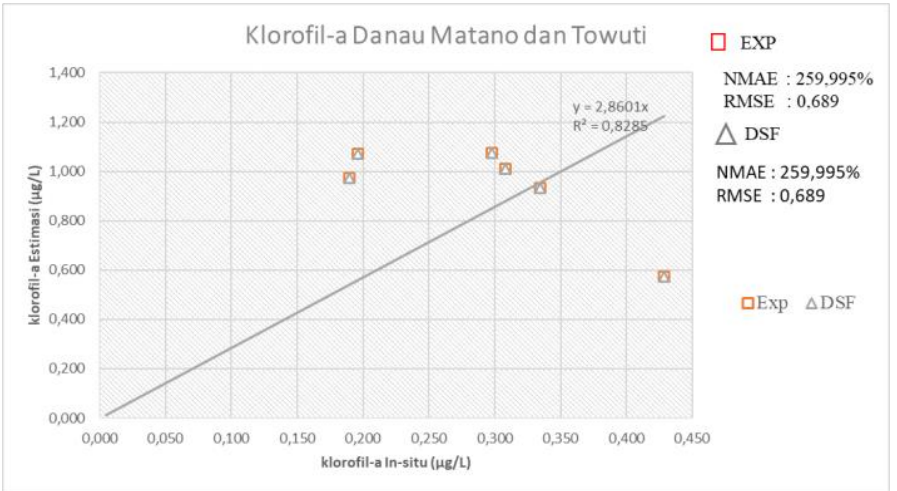

Gambar 8. Grafik Hubungan antara nilai Klorofil-a
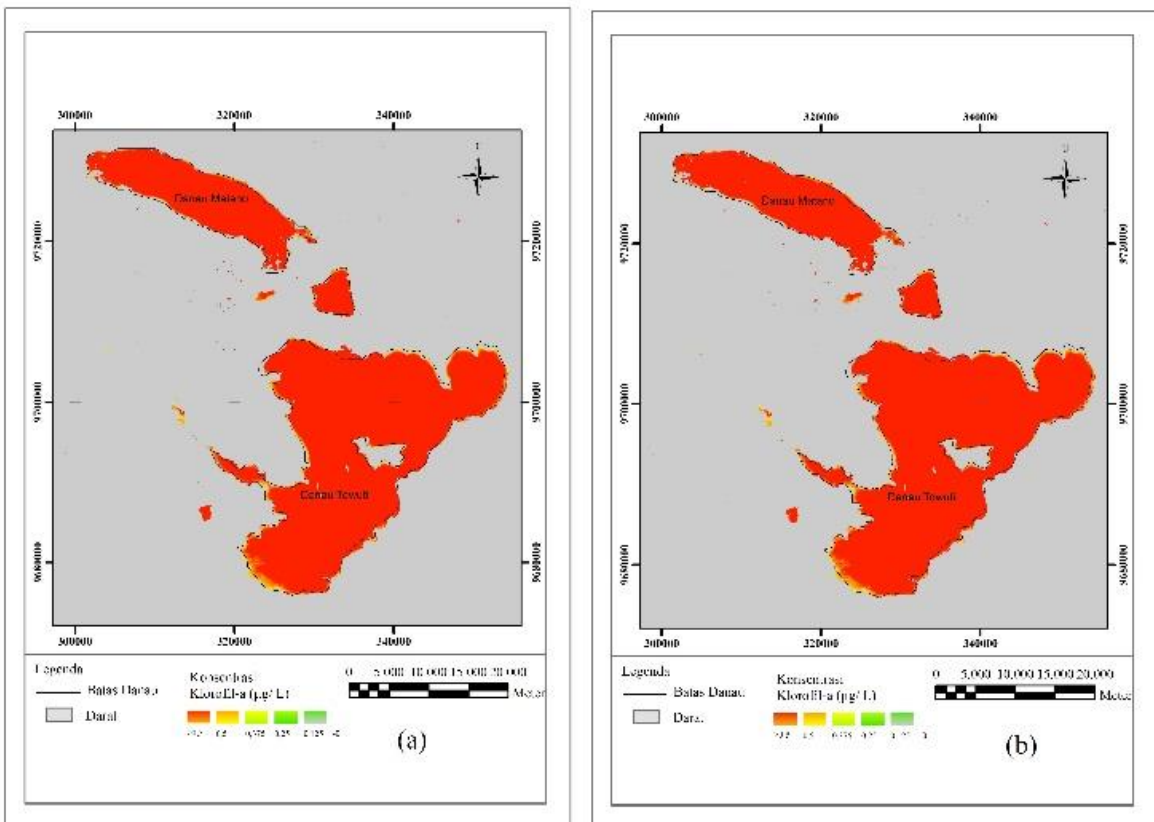

Gambar 9. Persebaran estimasi klorofil-a pada Danau Matano dan Towuti dengan koreksi (a) Exponential Extrapolation (b) Dark Spectrum Fitting 
Gambar 8 memperlihat hubungan antara nilai estimasi dari kedua metode. Didapatkan ploting titik yang sama antara kedua metode dikarenakan nilai dari $\operatorname{Rrs}(\lambda)$ kedua metode juga sama. Menghasilkan nilai estimasi klorofil-a yang sama.

Gambar 9 menunjukkan persebaran klorofil-a pada Danau Matano dan Towuti, semakin merah menunjukkan semakin tinggi konsentrasi dari klorofil-a tersebut. Pada gambar tersebut perairan termasuk kategori Oligotrof yang mana pada perairan tersebut mengandung unsur hara kadar rendah, kualitas air bersifat alamiah, belum tercemar dari Nitrogen dan Fosfor.

\section{Hasil Pengolahan Nilai Estimasi Klorofil-a Perairan Pulau Poteran, Sumenep}

Hasil perhitungan nilai estimasi klorofil-a di Perairan Pulau Poteran, Sumenep setelah diuji dengan dua metode koreksi atmosfer ditunjukkan oleh Tabel 11 di bawah ini.

$\underline{\text { Tabel 11. Hasil nilai estimasi klorofil-a Perairan Pulau Poteran, Sumenep }}$

\begin{tabular}{cccc}
\hline \hline \multirow{2}{*}{ Stasiun } & \multicolumn{3}{c}{ Klorofil-a $(\mu \mathrm{g} / \mathrm{L})$} \\
\cline { 2 - 4 } & In situ & Exp & DSF \\
\hline St.1 & 0,278 & $\mathrm{NaN}$ & $-0,217$ \\
\hline St.3 & 0,298 & 0.879 & 0,839 \\
\hline St.4 & 0,28 & $\mathrm{NaN}$ & 0,857 \\
\hline St.5 & 0,254 & $\mathrm{NaN}$ & 0,799 \\
\hline St.6 & 0,386 & $\mathrm{NaN}$ & 0,719 \\
\hline St.7 & 0,459 & $\mathrm{NaN}$ & 0,585 \\
\hline St.9 & 0,332 & $\mathrm{NaN}$ & 0,715 \\
\hline \hline
\end{tabular}

Hasil dari estimasi nilai klorofil-a pada metode Exponential Extrapolation hanya pada titik pengamatan dengan kode St.3 yang dapat terdefinisi, hal ini disebabkan oleh nilai $\operatorname{Rrs}(\lambda)$ yang juga tidak terdefinisi selain untuk titik pengamatan dengan kode St.3. hal ini menandakan bahwa nilai $\operatorname{Rrs}(\lambda)$ berpengaruh besar pada nilai estimasi klorofil-a. Hasil dari nilai estimasi dari Perairan Pulau Poteran masuk dalam klasifikasi oligotrof karena nilai estimasi lebih kecil dari $2 \mu \mathrm{g} / \mathrm{L}$.

Tabel 12. Perhitungan R2, NMAE, RMSE klorofil-a Pulau Poteran, Sumenep

\begin{tabular}{ccccc}
\hline $\begin{array}{c}\text { Metode } \\
\text { Koreksi }\end{array}$ & $\mathrm{R}^{2}$ & $\mathrm{r}$ & $\mathrm{NMAE}(\%)$ & $\mathrm{RMSE}(\mu \mathrm{g} / \mathrm{L})$ \\
\hline $\mathrm{Exp}$ & $\mathrm{NaN}$ & $\mathrm{NaN}$ & $\mathrm{NaN}$ & $\mathrm{NaN}$ \\
\hline $\mathrm{DSF}$ & 0,005 & 0,074 & 93,258 & 0,454 \\
\hline \hline
\end{tabular}

Melihat Tabel 12 nilai koefisien korelasi (r) dan koefisien Determinasi $\left(\mathrm{R}^{2}\right)$ tidak dapat terdefinisikan ketika dilakukan dengan metode Exponential Extrapolation tidak dapat di tunjukan keterkaitan antara nilai estimasi dan nilai in-situ klorofil-a. Pada nilai koefisien korelasi (r) dan koefisien Determinasi $\left(\mathrm{R}^{2}\right)$ yang dilakukan melalui koreksi atmosfer dengan metode Dark Spectrum Fitting diperoleh nilai 0,074 untuk koefisien korelasi dan 0,005 untuk koefisien determinasi. Namun dengan nilai tersebut bisa dikatakan bahwa korelasi antara nilai estimasi dan nilai in-situ dari klorofil-a korelasinya lemah. Berikut gambaran dari persebaran klorofil-a di Pulau Poteran, Sumenep. 


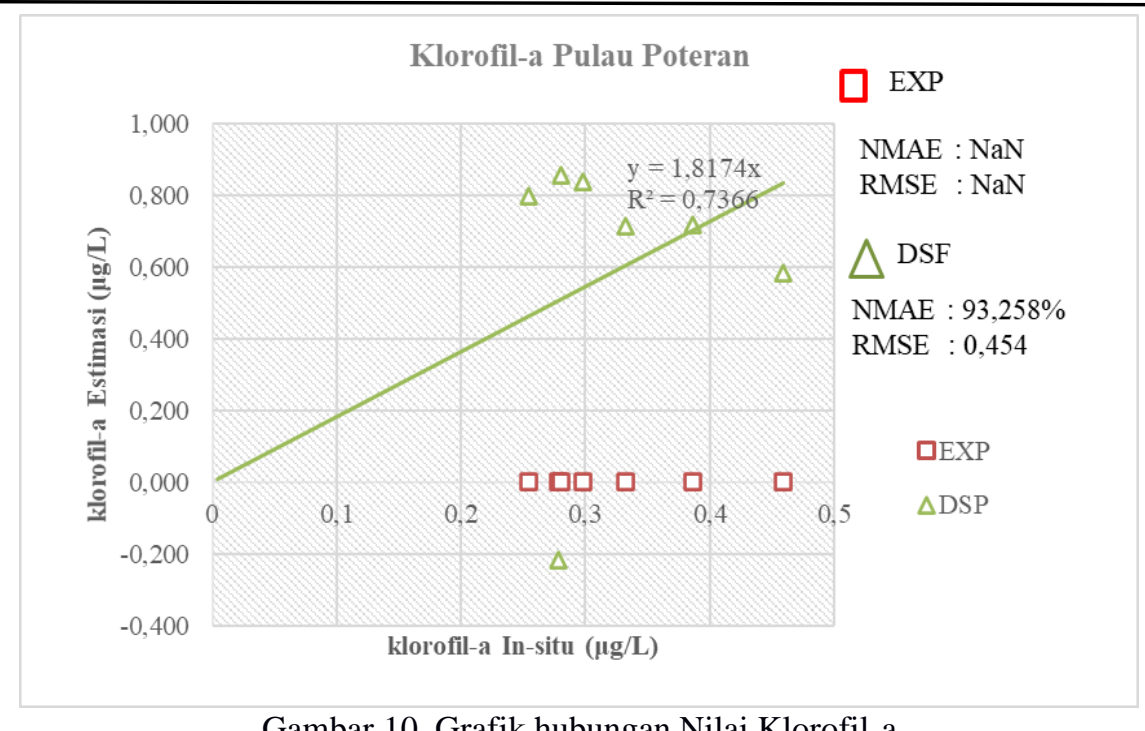

Gambar 10. Grafik hubungan Nilai Klorofil-a

Gambar 10 menunjukkan hubungan antara nilai estimasi klorofil-a dari kedua metode. Didapatkan ploting titik yang sangat berbeda antara kedua metode dikarenakan nilai dari $\operatorname{Rrs}(\lambda)$ salah satu metode tidak dapat terdefinisi sehingga menyebabkan sulit menarik hubungan antara kedua hasil tersebut.
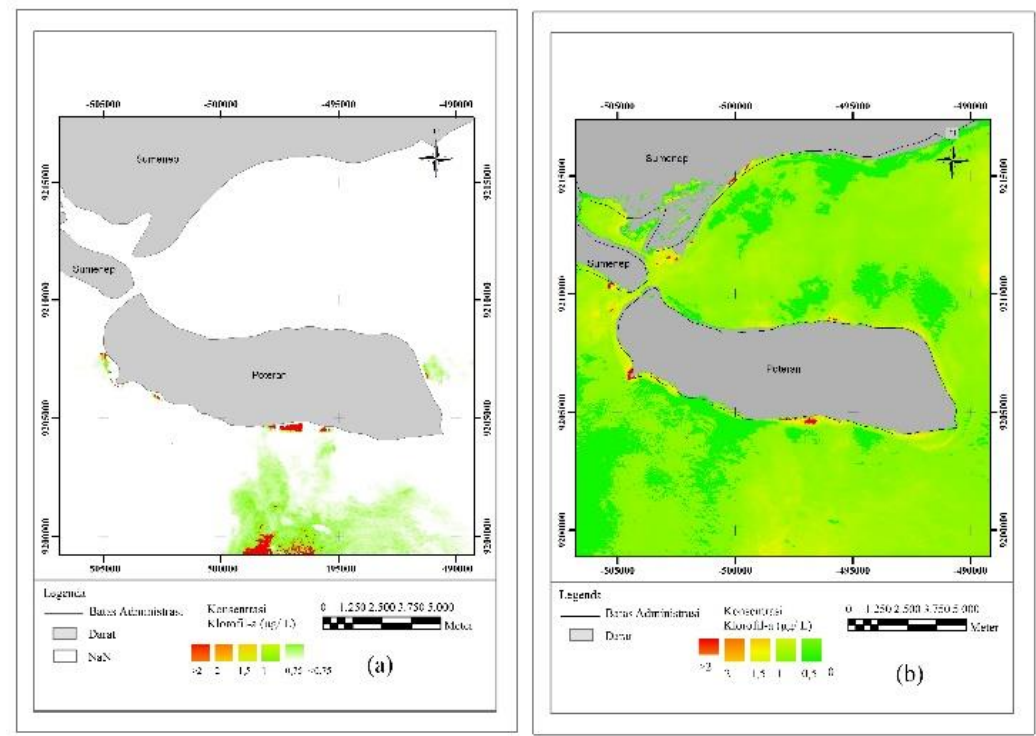

Gambar 11. Gambaran persebaran klorofil-a Pulau Poteran dengan melalui metode (a) Exponential Extrapolation (b) Dark Spectrum Fitting.

Gambar 11 menunjukan tingkat konsentrasi klorofil-a. Semakin merah menunjukkan semakin tinggi konsentrasi klorofil-a di tempat tersebut. Umumnya konsentrasi klorofil-a akan tinggi di sepanjang pesisir dan kemudian semakin berkurang menuju lepas pantai. Untuk Gambar 11 (a) dari klorofil-a di perairan Pulau Poteran menggunakan metode Exponential Extrapolation, namun dalam kasus ini titik-titik pengamatan tidak dapat terdefinisi yang menyebabkan tidak dapat diperoleh nilai dari klorofil-a. Pada gambar tersebut perairan termasuk kategori Oligotrof yang mana pada perairan tersebut mengandung unsur hara kadar rendah, kualitas air bersifat alamiah, belum tercemar dari Nitrogen dan Fosfor.

\section{Hasil Pengolahan Nilai Estimasi Klorofil-a Danau Kasumigaura, Jepang}

Hasil perhitungan nilai estimasi klorofil-a di Danau Kasumigaura, Jepang setelah diuji dengan dua metode koreksi atmosfer ditunjukkan oleh Tabel 13 di bawah ini. 
Tabel 13. Hasil nilai estimasi klorofil-a Danau Kasumigaura, Jepang

\begin{tabular}{cccc}
\hline \hline \multirow{2}{*}{ Stasiun } & \multicolumn{3}{c}{ Klorofil-a $(\mu \mathrm{g} / \mathrm{L})$} \\
\cline { 2 - 4 } & In situ & Exp & DSF \\
\hline St, 1 & 0,696 & 0,178 & 0,149 \\
\hline St, 2 & 0,845 & 0,150 & 0,240 \\
\hline St,3 & 0,902 & 0,206 & 0,213 \\
\hline St,5 & 0,898 & 0,224 & 0,221 \\
\hline st,6 & 0,883 & 0,208 & 0,187 \\
\hline st,7 & 0,939 & 0,199 & 0,269 \\
\hline st, 8 & 0,095 & 0,293 & 0,256 \\
\hline \hline
\end{tabular}

Pada Tabel 12 menunjukkan hasil dari nilai estimasi dari Danau Kasumigaura masuk dalam klasifikasi oligotrof karena nilai estimasi lebih kecil dari $2 \mu \mathrm{g} / \mathrm{L}$.

\begin{tabular}{ccccc} 
Tabel 14. Perhitungan & \multicolumn{4}{c}{$\mathrm{R} 2$, NMAE, RMSE klorofil-a Danau Kasumigaura, Jepang } \\
\hline \hline $\begin{array}{c}\text { Metode } \\
\text { Koreksi }\end{array}$ & $\mathrm{R}^{2}$ & $\mathrm{r}$ & NMAE $(\%)$ & $\mathrm{RMSE}(\mu \mathrm{g} / \mathrm{L})$ \\
\hline Exp & 0,548 & $-0,740$ & 36,500 & 0,625 \\
\hline DSF & 0,036 & $-0,189$ & 40,326 & 0,604 \\
\hline \hline
\end{tabular}

Pada Tabel 14 diperoleh koefisien korelasi bernilai negatif sebesar -0,740 untuk Exponential Extrapolation koefisien korelasi ini menunjukkan hubungan yang berlawanan dan -0,189 untuk Dark Spectrum Fitting, koefisien korelasi ini menunjukkan hubungan yang berlawanan . untuk koefisien determinasi pada koreksi atmosfer Exponential Extrapolation dengan nilai 0,548 dan 0,036 untuk Dark Spectrum Fitting menunjukkan korelasi yang lemah.

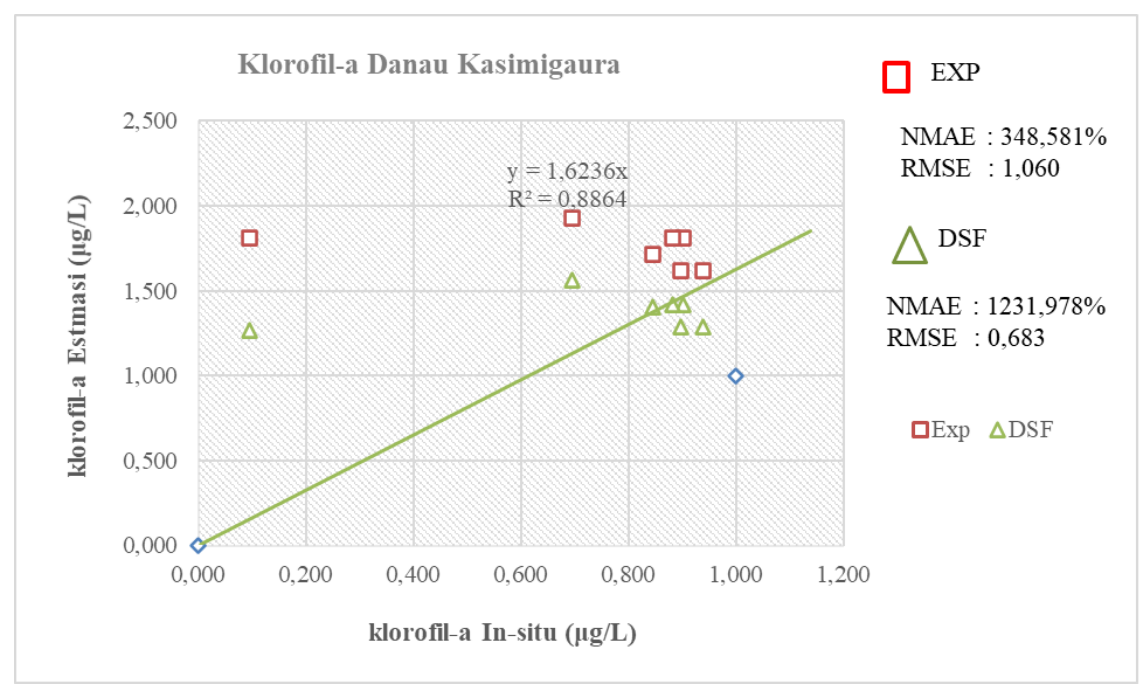

Gambar 12. Grafik hubungan nilai Klorofil-a

Gambar 12 memperlihatkan hubungan antara nilai estimasi klorofil-a dari kedua metode. Didapatkan ploting titik yang berbeda antara kedua metode dikarenakan nilai dari $\operatorname{Rrs}(\lambda)$. Jika melihat grafik tersebut dapat dikatakan dua variabel ini memiliki hubungan yang tinggi. 

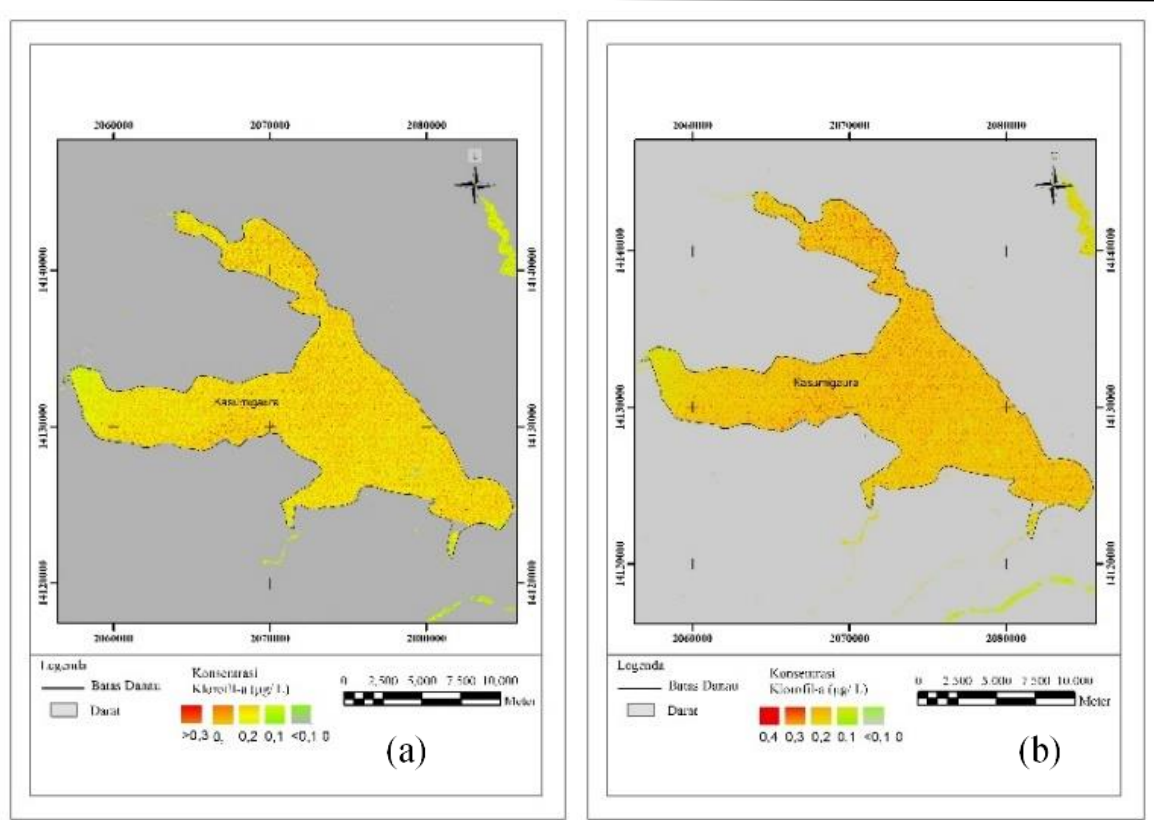

Gambar 13. Gambaran persebaran klorofil-a setelah melalui koreksi atmosfer dengan metode (a) Exponential Extrapolation (b) Dark Spectrum Fitting

Selanjutnya, mengenai konsentrasi klorofil-a di Danau Kasumigaura ditunjukkan oleh Gambar 13. Tingkat warna semakin mendekati merah maka semakin tinggi konsentrasi klorofil-a pada titik tersebut. Pada gambar tersebut perairan termasuk kategori Oligotrof yang mana pada perairan tersebut mengandung unsur hara kadar rendah, kualitas air bersifat alamiah, belum tercemar dari Nitrogen dan Fosfor.

\section{Kesimpulan}

Dari hasil penelitian yang dilakukan didapatkan kesimpulan bahwa metode Dark Spectrum Fitting menunjukkan hasil yang lebih baik dibandingkan dengan metode Exponential Extrapolation. Hal ini didukung dengan hasil nilai korelasinya dengan data in-situ sebesar 0,826 pada Danau Matano dan Towuti, 0,844 untuk perairan Pulau Poteran, dan 0,9471 untuk Danau Kasumigaura. Serta nilai NMAE 87,121\% untuk Danau Matano dan Towuti, 165,017\% untuk Perairan Pulau Poteran, dan 62,045\% untuk Danau Kasumigaura. Selain itu, hasil penelitian menunjukan bahwa pengaruh dari metode koreksi atmosfer mempengaruhi nilai estimasi klorofil-a, dikarenakan hasil koreksi atmosfer akan mempengaruhi nilai $\operatorname{Rrs}(\lambda)$ yang mana nilainya dijadikan acuan untuk menghitung nilai estimasi Klorofil-a. Hal ini dibuktikan dengan pada data Danau Matano dan Towuti nilai $\operatorname{Rrs}(\lambda)$ yang sama menyebabkan nilai estimasi klorofil-a yang sama. Untuk data pada Perairan Pulau Poteran dengan menggunakan metode Exponential Extrapolation tidak dihasilkan nilai $\operatorname{Rrs}(\lambda)$ sehingga menyebabkan tidak diperolehnya nilai klorofil-a pada metode ini Exponential Extrapolation. Untuk Danau Kasumigaura nilai klorofil-a bergantung dengan nilai $\operatorname{Rrs}(\lambda)$.

\section{Ucapan Terimakasih}

Penulis menyampaikan terima kasih kepada Royal Belgian Institute of Natural Sciences (RBINS) yang telah menyediakan perangkat lunak ACOLITE, dan kepada Advanced Research Laboratory A504, University of Tsukuba, Tsukuba, Japan yang telah menyediakan data Danau Kasumigaura.

\section{Daftar Pustaka}

Antoine, D., \& Morel, A. (1999). A multiple scattering algorithm for atmospheric correction of remotely sensed ocean colour (MERIS instrument): Principle and implementation for atmospheres carrying various aerosols including absorbing ones. International Journal of Remote Sensing, 20(9), 1875-1916. https://doi.org/10.1080/014311699212533 
Bailey, S. W., Franz, B. A., \& Werdell, P. J. (2010). Estimation of near-infrared water-leaving reflectance for satellite ocean color data processing. Optics Express, 18(7), 7521-7527. https://doi.org/10.1364/OE.18.007521

Dogliotti, A. I., Ruddick, K., \& Guerrero, R. (2016). Seasonal and inter-annual turbidity variability in the Río de la Plata from 15 years of MODIS: El Niño dilution effect. Estuarine, Coastal and Shelf Science, 182, 27-39. https://doi.org/10.1016/j.ecss.2016.09.013

Gao, B. C., Montes, M. J., Li, R. R., Dierssen, H. M., \& Davis, C. O. (2007). An atmospheric correction algorithm for remote sensing of bright coastal waters using MODIS land and ocean channels in the solar spectral region. IEEE Transactions on Geoscience and Remote Sensing, 45(6), 1835-1843. https://doi.org/10.1109/TGRS.2007.895949

Gordon, H. R., \& Wang, M. (1994). Retrieval of water-leaving radiance and aerosol optical thickness over the oceans with SeaWiFS: a preliminary algorithm. Applied Optics, 33(3), $443-452$. http://www.ncbi.nlm.nih.gov/pubmed/20862036

Jaelani, L. M., Setiawan, F., Wibowo, H., \& Apip. (2015). Pemetaan Distribusi Spasial Konsentrasi Klorofil-A dengan Landsat 8 di Danau Matano dan Danau Towuti, Sulawesi Selatan. Pertemuan Ilmiah Tahunan Masyarakat Ahli Penginderaan Jauh Indonesia, XX, 456-463. https://doi.org/10.13140/RG.2.1.4278.6000

Laili, N., Arafah, F., Jaelani, L. M., Subehi, L., Pamungkas, A., Koenhardono, E. S., \& Sulisetyono, A. (2015). Development of Water Quality Parameter Retrieval Algorithms for Estimating Total Suspended Solids and Chlorophyll-A Concentration using Landsat-8 Imagery at Poteran Island Water. ISPRS Annals of Photogrammetry, Remote Sensing and Spatial Information Sciences, II-2/W2(October), 55-62. https://doi.org/10.5194/isprsannalsII-2-W2-55-2015

Salem, S. I., Higa, H., Kim, H., Kazuhiro, K., Kobayashi, H., Oki, K., \& Oki, T. (2017). Multi-algorithm indices and look-up table for chlorophyll-a retrieval in highly turbid water bodies using multispectral data. Remote Sensing, 9(6). https://doi.org/10.3390/rs9060556

Vanhellemont, Q. (2019). Adaptation of the dark spectrum fitting atmospheric correction for aquatic applications of the Landsat and Sentinel-2 archives. Remote Sensing of Environment, 225(November 2018), $175-192$. https://doi.org/10.1016/j.rse.2019.03.010

Vanhellemont, Q., \& Ruddick, K. (2014). Turbid wakes associated with offshore wind turbines observed with Landsat 8. Remote Sensing of Environment. https://doi.org/10.1016/j.rse.2014.01.009

Vanhellemont, Q., \& Ruddick, K. (2015). Advantages of high quality SWIR bands for ocean colour processing: Examples from Landsat-8. Remote Sensing of Environment, 161, 89-106. https://doi.org/10.1016/j.rse.2015.02.007

Vanhellemont, Q., \& Ruddick, K. (2016). ACOLITE FOR SENTINEL-2: AQUATIC APPLICATIONS OF MSI IMAGERY. In ESA Special Publication SP. https://odnature.naturalsciences.be/remsem/acolite-

Vanhellemont, Q., \& Ruddick, K. (2018). Atmospheric correction of metre-scale optical satellite data for inland and coastal water applications. Remote Sensing of Environment, 216, 586-597. https://doi.org/10.1016/j.rse.2018.07.015

Woodcock, C.; E. A. (2008). 1018 Free Access to Landsat Imagery Teach by the Book Science Education : Science, 320(May), 1011-1012. 